\title{
Chlorogenic acid alleviates sepsis-induced endothelial barrier dysfunction and the underlying mechanism
}

\section{Zisen Zhang}

Third Military Medical University Daping Hospital and Research Institute of Surgery

\section{Yue Wu}

Third Military Medical University Daping Hospital and Research Institute of Surgery

\section{Yu Zhu}

Third Military Medical University Daping Hospital and Research Institute of Surgery

\section{Xiao-yong Peng}

Third Military Medical University Daping Hospital and Research Institute of Surgery

\section{Ming-ying Xue}

Third Military Medical University Daping Hospital and Research Institute of Surgery

\section{Tao Li ( $D$ lt200132@163.com )}

Third Military Medical University Daping Hospital and Research Institute of Surgery

\section{Liangming Liu ( $\nabla$ liangmingliu@yahoo.com )}

Third Military Medical University Daping Hospital and Research Institute of Surgery

\section{Research}

Keywords: Sepsis, Chlorogenic acid, Endothelial barrier function, ZO-1, VE-cadherin

Posted Date: May 20th, 2020

DOI: https://doi.org/10.21203/rs.3.rs-23474/v2

License: (c) (1) This work is licensed under a Creative Commons Attribution 4.0 International License. Read Full License 
The authors have withdrawn this preprint from Research Square 